\title{
POLÍTICA PÚBLICA DA PREVIDÊNCIA SOCIAL E TRABALHADORES DA PESCA ARTESANAL: DILEMAS ESTRUTURAIS EM CONTEXTOS CONJUNTURAIS DA COVID-19
}

\author{
Public policy of Social Security and artisanal fishing workers: structural dilemmas in conjunctural \\ contexts of the COVID-19
}

\author{
Catia Antonia da Silva ${ }^{1}$ \\ Professora Titular (DGEO/FFP/UERJ) \\ catia.antonia@gMail.com \\ Karla da Silva Sampaio \\ Bolsista PIBIC-CNPq pesquisadora NUTEMC/FFP/UERJ \\ karlasampaiooo@yahoo.com.br \\ Carolina Lourival Buch \\ Graduada em Geografia e pesquisadora NUTEMC/FFP/UERJ \\ carol_buch@hotmail.com \\ Rodrigo Correa Euzêbio \\ Mestre em Geografia -PPGG/FFP/UERJ e pesquisador NUTEMC/FFP/UERJ \\ euzebiogeo@gmail.com \\ Pedro Benício Almeida Pinto \\ Doutorando em História Social (PPGHS) e pesquisador NUTEMC/FFP/UERJ \\ benicio_pedro@hotmail.com
}

Artigo enviado para publicação em 30/04/2020 e aceito em 05/05/2020

DOI: $10.12957 /$ tamoios.2020.50764

\begin{abstract}
Resumo
A Lei N $\mathrm{N}^{\mathrm{0}}$ 13.982/2020, referente ao auxílio emergencial aos trabalhadores em condição de vulnerabilidade social foi sancionada pelo presidente da República em 02 de abril de 2020 como forma de manutenção das medidas de distanciamento social. Por três meses a lei garante auxílio financeiro durante período de enfrentamento da pandemia decorrente do Coronavírus (Sars-CoV-2). A Articulação dos Pescadores e Pescadoras do Sul e Sudeste do Brasil lançou um manifesto que alerta sobre os limites do acesso dos trabalhadores da pesca artesanal e pequenos agricultores ao auxílio, apesar de suas condições de pobreza e vulnerabilidade em tempos de isolamento social. Questão de grande importância porque remete ao debate de como as políticas públicas se realizam no território. Existe um distanciamento entre a proposta de lei e a efetivação do acesso dos direitos. Assim, o artigo objetiva realizar uma reflexão sobre os limites e possibilidades de acesso aos direitos trabalhistas e aos direitos previdenciários pelos produtores rurais e extrativistas no Brasil. Busca analisar a conjuntura social e política engendrada pela crise da COVID-19 refletindo sobre a estrutura da Previdência Social no Brasil, com foco nas peculiaridades do segurado especial, que acaba por contribuir nas dificuldades de acesso aos direitos sociais e na proteção assistencial dos pescadores e pescadoras em tempos de pandemia.
\end{abstract}

Palavras-chave: política pública; pescadores artesanais; direito previdenciário; conjuntura; Coronavírus.

\begin{abstract}
The Law N. 13,982/2020, referring to emergency assistance to workers in conditions of social vulnerability, was sanctioned by the President of the Republic on April 2, 2020, as a way of maintaining social distance measures, for three months the law guarantees financial assistance for the period facing the public health emergency of international importance due to the Coronavirus (Sars-CoV-2). The Articulation of Fishermen and Fishermen in the South and Southeast of Brazil launched a manifesto that warns about the limits of access for artisanal fisheries workers and small farmers to aid, despite their conditions of poverty and vulnerability in times of social isolation. This issue is of great importance because it refers to the debate on how public policies are carried out in the territory. There is a gap between the proposed law and effective access to rights. Thus, the article aims to reflect on the limits and possibilities of access to labor rights and social security rights by rural and extractivist producers in Brazil, seeking to analyze the social and political conjuncture engendered by the COVID crisis19 and reflect on the structure of Social Security in Brazil, with regard to the peculiarities of the special insured, which ends up contributing to the difficulties of access to social rights and to the assistance protection of fishermen in times of pandemic.
\end{abstract}

Keywords: public policy, artisanal fishermen, social security law, conjuncture and Coronavirus. 


\section{Introdução}

A Lei $\mathrm{N}^{\mathrm{O}}$ 13.982, de 02 de abril de 2020, sancionada pelo presidente da República, que estabelece medidas excepcionais de proteção social a serem adotadas durante o período de enfrentamento da emergência de saúde pública de importância internacional decorrente da expansão de contágio pelo novo subtipo de Coronavírus (Sars-CoV-2), cujo tema foi encaminhado e aprovado pelo Congresso Nacional, deixará de fora inúmeros trabalhadores da pesca artesanal e pequenos agricultores que estão na categoria de Segurado Especial na Previdência Social, conforme anunciado no Manifesto da Articulação de Pescadores e Pescadoras do Sul e Sudeste, divulgado em 06 de abril de 2020 (APPSULSE, 2020) Com base nesse dilema, o artigo busca analisar, na conjuntura da Crise da COVID-19, os problemas dos trabalhadores da pesca em relação ao acesso à Previdência Social e as dificuldades de acesso à política emergencial. Nesse sentido, o artigo divide-se em três seções: a primeira apresenta a demanda e o contexto conjuntural de criação da lei que regula a política emergencial; a segunda seção trata de analisar a estrutura da Previdência Social, seus processos de informatização e os limites do sistema; a terceira seção remete aos resultados das lutas e reivindicações dos pescadores. Em todas as seções, que têm o caráter narrativo e explicativo das ações previdenciárias e dos contextos conjunturais, buscamos relacionar com a reflexão geográfica da política pública.

\section{Política pública, direito trabalhista e previdenciário e pesca artesanal na conjuntura da crise da COVID-19: o que esse debate tem a ver com a Geografia?}

Trata-se de uma questão central que se inscreve na forma como a política pública se realiza no território. Nesse sentido, o presente artigo visa contribuir na compreensão do tempo presente, marcado pelos contextos de crise sanitária, social e econômica engendrada pela rápida expansão do vírus conhecido popularmente como Coronavírus, responsável pela doença COVID-19, amplamente divulgada como tendo origem na China no final do ano de 2019. A capacidade de expansão do vírus segue a lógica da globalização, em que a velocidade da circulação de pessoas na escala mundo, fez com que em menos de três meses tenha chegado a mais de 180 países. A capacidade de transmissibilidade, morbilidade e letalidade da COVID19 engendrou grande mobilização por parte do Estado chinês com o fechamento das fronteiras, o isolamento geográfico e o distanciamento físico-social. E esse tornou-se um modelo, orientado pela Organização Mundial de Saúde (OMS, 2020) de política contra a expansão descontrolada do vírus que leva ao colapso dos sistemas de saúde. No Brasil, o primeiro caso confirmado de doente da COVID-19 foi registrado no estado de São Paulo no dia 26 de fevereiro de 2020. No 30 de abril de 2020 (OMS, 2020) o Brasil passa a ter mais casos confirmados (85.380 casos confirmados e 5.901 óbitos) a mais que a China (83.944 casos e 4.637 mortos).

Com a confirmação da transmissão comunitária na semana do dia 16 de março, governos estaduais como os do Rio de Janeiro e São Paulo, estados até então mais afetados, passam a decretar um conjunto de ações junto com os prefeitos das Regiões Metropolitanas, tais como o fechamento de empresas de serviços públicos, privados e comércio. Ficando apenas liberado as atividades definidas como essenciais: saúde, bancos, mercados alimentícios, farmácias, logística alimentar, infraestrutura telefonia, energia elétrica e de saneamento básico. Mesmo assim, São Paulo e Rio de Janeiro apresentam os maiores caso oficiais de infectados e de números de óbitos, com forte pressão ao sistema de saúde. Nota-se claramente o colapso no sistema de saúde na maios parte das capitais brasileiras. O impacto nas comunidades pesqueiras foi e está sendo sentido. Com o crescente número de informações, por vezes desconexas e contraditórias levou, a população ao medo. Primeiro, o medo de continuar as atividades de 
venda nos comércios locais, junto aos atravessadores e, em segundo, no fazer coletivo comunitário de reparo de embarcações e redes fizeram surgir uma série de dúvidas e receios. Muitos pararam de pescar porque não tinham para quem vender, já que o escoamento da produção pela venda direta e local para o consumidor foi impossibilitada pelas restrições de circulação da população e também dos atravessadores. Outros pescadores e pescadoras que vivem em comunidades muito isoladas e que gastam muitos recursos até chegarem aos mercados de peixes nas cidades viram esses mercados fecharem. As entidades representativas e os movimentos sociais na área de pesca iniciaram rapidamente formas de mobilização por meio das redes sociais já historicamente estabelecidas e, na atual conjuntura, com o uso das redes de comunicação e informação - Facebook e WhatsApp, dentre outros, produzindo vários grupos sociais em diferentes regiões do Brasil.

Da mesma forma, a expansão do vírus, a expansão da informação e das formas de inseguranças, foram constituindo um conjunto de incertezas que se somavam e se somam a outros trabalhadores urbanos e rurais pelo Brasil a fora. Os debates da renda e do trabalho passam a disputar o campo da política. À luz de outros exemplos de países que passam a produzir políticas de assistência social em contexto de instabilidade econômica, pressionaram o Congresso Nacional a ter uma postura, assim como as diferentes esferas do poder executivo. Assim, no Congresso Nacional sofre uma enxurrada de demandas sobre medidas que garantam a seguridade social, principalmente os problemas de pobreza e falta de renda, que fez o deputado Federal Marcelo Aro (PP) a propor ao parlamento a Emenda à proposta de 2017 do Projeto de Lei 9.236 de Eduardo Barbosa (PSDB) que inicialmente era uma proposta de garantia de renda de idosos e pessoas em condição de deficiência e vulnerabilidade que tivessem acesso ao Benefício de Prestação Continuada (BPC). A inclusão no PL de um auxílio emergencial no valor de 500 reais durante contexto da crise da COVID-19 foi para votação na Câmara de Deputados em 26 de março, sendo aprovado com valor de 600 reais, embora o Ministro da Economia Paulo Guedes houvesse proposto inicialmente o valor de 200 Reais. No final da votação entre os deputados, a proposta esperou quatro dias para ser aprovada no Senado, em 30 de março, e nesse contexto já recebendo as demandas de vários movimentos sobre as categorias de trabalhadores que ficariam de fora do auxílio. Conforme se observa no Quadro 1:

Quadro 1 - Tempo da tramitação do auxílio emergencial da crise da COVID-19

\begin{tabular}{|l|l|l|l|}
\hline Data & Ação & Responsável & Resultado \\
\hline 2017 & $\begin{array}{l}\text { Projeto de Lei } \\
9236 / 2017\end{array}$ & $\begin{array}{l}\text { Eduardo Barbosa } \\
(\text { PSDB-MG })^{2}\end{array}$ & $\begin{array}{l}\text { Propõe regulamenta requisitos para acesso ao } \\
\text { Benefício de Prestação Continuada (BPC) aos } \\
\text { idosos e deficientes que vivem em condição de } \\
\text { vulnerabilidade. }\end{array}$ \\
\hline $26 / 03 / 2020$ & $\begin{array}{l}\text { Aprova Projeto } \\
\text { de Lei } 9236 / 17\end{array}$ & $\begin{array}{l}\text { Substitutivo } \\
\text { deputado Marcelo } \\
\text { Aro (PP-MG) }\end{array}$ & $\begin{array}{l}\text { Por acordo entre os partidos, deverá ser } \\
\text { incluído no texto, pelo relator, uma bolsa } \\
\text { emergencial de R\$ 500,00 para pessoas } \\
\text { vulneráveis no contexto da COVID-19, } \\
\text { durante 3 meses. }\end{array}$ \\
& & $\begin{array}{l}\text { Marcelo Aro } \\
\text { depois de conversar } \\
\text { com Vitor Hugo } \\
\text { (PSL-GO) }\end{array}$ & $\begin{array}{l}\text { Passou para R\$ 600 reais e R\$ 1.200 para } \\
\text { mulher chefe de família. }\end{array}$ \\
\hline
\end{tabular}


Política pública da previdência social e trabalhadores da pesca artesanal: dilemas estruturais em contextos conjunturais da covid-19

\begin{tabular}{|c|c|c|c|}
\hline $30 / 03 / 2020$ & $\begin{array}{l}\text { Lei 13.982, de } \\
2020\end{array}$ & $\begin{array}{lr}\text { O PL 873/2020 é do } \\
\text { senador } & \text { Randolfe } \\
\text { Rodrigues } & \text { (Rede- } \\
\text { AP) e foi } & \text { relatado } \\
\text { pelo } & \text { senador } \\
\text { Esperidião } & \text { Amin } \\
\text { (PP-SC) } & \end{array}$ & $\begin{array}{l}\text { Os sócios de empresas que estão inativas e as } \\
\text { mães adolescentes (não contempladas pela lei } \\
\text { porque o auxílio é destinado aos maiores de } 18 \\
\text { anos). Também estende para aos lares } \\
\text { monoparentais a possibilidade de receberem } \\
\text { duas cotas do auxílio emergencial (R\$ 1.200), } \\
\text { uma vez que a lei havia restrito essa } \\
\text { possibilidade apenas às mulheres chefes de } \\
\text { família. }\end{array}$ \\
\hline & $\begin{array}{l}\text { Lei } \\
13.982 / 2020^{3} \text {. }\end{array}$ & $\begin{array}{lr}\text { Presidente } & \text { da } \\
\text { República } & \text { Jair } \\
\text { Bolsonaro } & \end{array}$ & $\begin{array}{l}\text { As maiores de idade sem emprego formal, mas } \\
\text { que estão na condição de trabalhadores } \\
\text { informais, microempreendedores individuais } \\
\text { (MEI) ou contribuintes da Previdência Social. } \\
\text { Também é necessário ter renda familiar mensal } \\
\text { inferior a meio salário mínimo per capita ou } \\
\text { três salários mínimos no total e não ser } \\
\text { beneficiário de outros programas sociais ou do } \\
\text { seguro-desemprego }\end{array}$ \\
\hline $\begin{array}{l}02 \text { de abril de } \\
2019\end{array}$ & Lei $13.982 / 2020$ & $\begin{array}{l}\text { Caixa Econômica / } \\
\text { Ministério da } \\
\text { Cidadania }\end{array}$ & $\begin{array}{l}\text { CADASTRO ÚNICO PARA PROJETOS } \\
\text { SOCIAIS para os inscritos e para os não } \\
\text { inscritos ir para plataforma digital - conta } \\
\text { poupança digital da Caixa Econômica. }\end{array}$ \\
\hline
\end{tabular}

Fontes: Agência Câmara de Notícias https:/www.camara.leg.br/noticias/648766-deputados-analisam-em-plenario-criacao-de-auxilioemergencial-no-periodo-de-pandemia/ Jornal do Commercio de Comunicação. https://blogs.ne10.uol.com.br/jamildo/2020/03/26/camara-dosdeputados-aprova-auxilio-emergencial-de-r-600-para-pessoas-de-baixa-renda/ e Estadão. https://economia.estadao.com.br/noticias/geral,senado-aprova-auxilio-de-r-600-a-informais-intermitentes-e-meis, 70003253962

Durante esse período de tramitação, apesar de muitas contestações de vários grupos e entidades trabalhistas, no texto da lei os segmentos de trabalhadores que tiveram esse direito à renda emergencial assegurado foram os desempregados, beneficiários do sistema previdenciário como contribuinte individual, autônomos e trabalhadores informais com renda familiar mensal de até $\mathrm{R} \$ 522,50$ por pessoa ou renda total que não ultrapasse três salários mínimos - ver Quadro 2.

\section{Quadro 2 - Critérios de aprovação ao acesso à Política Emergencial - Lei 3.982/2020}

- Desempregado ou que exerça atividade na condição de:

- Microempreendedores individuais (MEI);

- Contribuinte individual da Previdência Social;

- Trabalhador Informal;

- Pertença à família cuja renda mensal por pessoa não ultrapasse meio salário mínimo ( $\mathrm{R} \$ 522,50)$, ou cuja renda familiar total seja de até 3 (três) salários mínimos ( $\$ 3.135,00)$.

Fonte: Caixa Econômica. Auxílio Emergencial. Disponível:

http://www.caixa.gov.br/auxilio/Paginas/default2.aspx\#calendario?utm_source=site_caixa\&utm_medium=botao_home\&utm_campaign=auxi lio

Diante do quadro de insegurança, houve várias tentativas de emendas enviadas pelos movimentos sociais ao Senado Federal para incluir ou esclarecer que grupos sociais estariam 
fora da política emergencial. A princípio o discurso e intencionalidade estavam voltados aos desempregados e pequenos empresários que estavam sem renda por conta das medidas de restrição de circulação da população que impediam o exercício pleno do trabalho. As categorias como produtores rurais (pescadores, agricultores, extrativistas de vegetais, garimpeiros, indígenas, dentre outros ficariam de fora). O que levou a Articulação de Pescadores e Pescadoras do Sul e Sudeste (APPSULSE) a divulgar manifesto citando a referência à Previdência Social como trabalhadores rurais, onde a categoria dos produtores rurais e, desse modo, os pescadores artesanais, são categorizados como Segurado Especial no sistema da Previdência Social. Como categoria que garante a manutenção da segurança alimentar da população e, portanto, atividade essencial, surge uma preocupação com a situação de vulnerabilidade social desses trabalhadores que encontram problemas estruturais de acesso aos direitos sociais e aos sistemas do INSS, e também ao acesso ao Seguro Desemprego do Pescador Artesanal, que é recebido como medida compensatória em período de proibição de pesca por conta do defeso, conforme veremos mais adiante.

O conceito de política pública refere-se à compreensão das intencionalidades e ações do Estado. Poulantzas (2000) já tinha anunciado sobre a compreensão da Ossatura do Estado, no que se refere ao poder de controle sobre o território, a cultura, o cotidiano e as formas de sociabilidade. Um dado importante da reflexão é a natureza do Estado moderno, baseado na calculabilidade, na impessoalidade e no poder onipresente, que Weber (2000) já tinha denominado de dominação burocrático-legal. O contexto conjuntural da COVID-19, em consonância com a característica de contágio do vírus, acompanha a aceleração e a simultaneidade do atual patamar da globalização. Como o vírus atua em todas as classes sociais, os níveis de mobilização pública se deram de acordo com o nível de mobilização da mídia e das classes médias. Assim, no campo político, nasce a disputa entre o pensamento liberal contra o isolamento e distanciamento social (enquanto política de contenção da expansão geométrica do vírus) e o pensamento a favor do isolamento e do fechamento de comércio, serviços e controle sobre mobilidade espacial. Num contexto de grandes cisões socioespaciais que antecede a crise, que consiste em desemprego, aumento da pobreza e com cerca de 45 milhões de pessoas fora do sistema de trabalho formal no Brasil, a COVID-19 coloca em pauta o acirramento da desigualdade social. As ações de implementação de ações emergenciais são propostas pela OMS (2020) e vão ser implementadas em diversos países que identificam a expansão da queda da renda, do desemprego, da fome e desespero. O Estado realiza o controle pela coerção punitiva, e esse controle social passa pela produção de legitimidade (POULANTZAS, 2000). A política pública nesse sentido é mediação do Estado com o duplo sentido: de coerção e de legitimidade e seu exercício sobre o território. Freitas (2015) lembra que é por meio da política que as ações do Estado se realizam no território, impondo normas, acessando recursos e provendo os interesses dos grupos hegemônicos. Desse modo, muitas vezes o texto da lei é produzido de forma tão genérica que parece tudo caber, mas não é para todos. A importância das mobilizações, denúncias e contestações dos movimentos sociais tornam-se fundamentais com aponta o Manifesto do APPSULSE (APPSULSE, 2020)

A crise de saúde pública decorrente da expansão do novo coronavírus em todo o mundo tem levado às medidas de isolamento social que vêm impactando as atividades agrícolas e pesqueiras, que apesar de serem consideradas de caráter essencial ao abastecimento alimentar do país, não estão reconhecidas no texto aprovado pelo Congresso Nacional. Com o comércio fechado, o isolamento social orientado pelas autoridades sanitárias nacionais e pela OMS, o medo de contaminação e as características dos nossos produtos que são perecíveis, nós pescadores artesanais e agricultores familiares estamos sem condições de escoamento e venda de nossa produção. Nossos produtos são comercializados em peixarias, pequenos mercados de bairro, mercados públicos locais. Nesse contexto, é considerável a redução da circulação de pessoas e fechamento do comércio em geral que sabemos que é de 
grande importância para a saúde pública de toda a sociedade. Mas precisamos dizer que os pequenos comerciantes autônomos e familiares que dependem de seus negócios e participam de nossa cadeia produtiva precisam sobreviver, assim como nossas famílias e comunidades locais que vivem da pesca e da agricultura. Já estamos sentindo os reflexos dessa crise de forma aguda, uma vez que não estamos conseguindo pagar as nossas dívidas. Não dá mais para esperar, sobretudo os pescadores e agricultores das regiões mais afetadas pela crise social, sanitária e econômica da Covid-19. O auxílio emergencial por mais amplo que pareça deixa de fora os segurados especiais, muitos pescadores que deram entrada no auxílio-defeso ou outros auxílios do INSS, até hoje não receberam. (APPSULSE, 2020)

As dúvidas se acentuam quando no corpo da lei se inscrevem as referências de quem não poderia receber o auxílio. O interessante é a análise do corpo do Estado. Assim o princípio de legitimação do Estado de Direito traz para o seio do Estado as contradições e paradoxos do ordenamento jurídico e da estrutura político-administrativa. Essas contradições fazem com que haja disputa de recursos e de ações de comprometimento (RIBEIRO, 2013; 2014). Com base nas eleições do final do ano, a capacidade de mobilização do Congresso Nacional, se antecipando ao poder executivo nas ações, demostra a complexidade do Estado e do jogo político.

A paralisação presencial dos serviços públicos e dos atendimentos nas agências da Previdência e a morosidade e incerteza no recebimento de auxílios já solicitados, levaram os grupos sociais à mobilização e questionamentos sobre as condições de trabalho dessa população em condições maiores de vulnerabilidades.

Desse modo, emergem na questão da crise emergencial o debate sobre os problemas históricos de acesso às políticas públicas. Dentre esses problemas ocorre que o sistema previdenciário brasileiro vive um processo de instabilidade de atendimento de seus beneficiários com seus funcionários em situação de aposentadoria e há muitos anos sem concurso para contratação e novos. O discurso do Governo Federal é de que o Estado precisa passar por um processo intenso de tecnificação e de informatização e com isso conseguirá "ampliar o atendimento" e reduzir os custos do sistema. Na verdade, em 2019, o que se observou foi que havia mais de 470 mil processos de solicitação de auxílios em atrasos.

Desse modo, a pandemia da COVID-19 não é somente uma questão sanitária em si. $\mathrm{Na}$ verdade, contribui para a compreensão mais acirrada de políticas públicas trabalhistas, previdenciárias e de assistência social que merecem ser estudadas pelas ciências humanas e sociais aplicadas. É nesse bojo que a geografia enquanto ciência social contribui para a compreensão de como as políticas públicas se realizam no território nacional. A ossatura do Estado, como explica Poulantzas (2000), refere-se sobretudo à estrutura burocrática em que a lei e o sistema político-social não garantem de fato o acesso da classe trabalhadora na sua totalidade. É verdade que a informatização desloca das relações locais interpessoais das formas de dominação, para as relações de poder e de controle são estabelecidas pelo Estado mediados pela impessoalidade, que os sistemas técnicos realizam. Weber (2000) lembra do poder de disposição como marcas da dominação burocrático-legal, que caracterizam o Estado Moderno, como a secularização com base no trabalho intelectual e na crença no progresso como pauta de superação de problemas. Weber demostra que a impessoalidade e a calculabilidade fazem parte dessa dominação que marca o Estado moderno por normatizações e ações mediados pelo corpo de funcionários públicos. A informatização emerge assim, como extensão dessas ações. Se o sistema informacional não funciona, é problema da técnica e nunca do projeto de Estado que sempre excluirá parte das pessoas que tem direito à assistência. Desse modo, vimos diariamente grandes filas na porta das agências da Caixa Econômica (CE) porque os beneficiários não conseguem resolver seu problema pelos dois aplicativos da CE. A compreensão da política pública emergencial inscreve-se no contexto das incertezas e das ações conjunturais.

Assim, a análise da conjuntura política, como analisou Marx (1968), é fundamental para 
compreender a produção social da ideologia e da velocidade do convencimento. Afinal, Ribeiro (2014), em seu livro Teorias da ação, já aponta para as formas produção da legitimação. Essas formas são construídas pela adesão e consenso mediado pelas grandes mídias televisivas. Assim, rede de televisão e de rádio noticia constantemente a crise do Coronavirus: aglomerações constantes nas portas das agências bancárias e a apresentação dos dados sobre infectados e óbitos, que acaba por invisibilizar outros problemas estruturais da política pública.

Assim, os limites das políticas públicas são os limites dos interesses do Estado moderno. Segundo Bobbio (1986), as formas políticas da democracia, como regime político e instrumentos de legitimidade, têm finalidades são contraditórias porque as políticas públicas não atingem a totalidade da população. Sobre essa questão da impossibilidade de uma abrangência global da ação estatal, Milton Santos (2007), afirmou que nem todos os brasileiros são cidadãos. Fundamental problematizar de acordo com os eventos da história a compreensão da cidadania. Assim, a política pública de caráter social é produzida com base em critérios que já se sabe que não atingirá a totalidade da população alvo, isso acontece com as políticas públicas estruturais da pesca e o mesmo, já vem acontecendo aos milhares de brasileiros em busca do auxílio emergência criado pela Lei $N^{0} 13.982 / 2020$.

\section{Complexidades estruturais em contextos de desigualdades em tempo de coronavírus}

Historicamente, a Previdência Social atua promovendo o reconhecimento dos direitos do trabalhador e de sua família por meio de serviços e benefícios, sendo uma política pública assistencialista e contributiva que tem por finalidade a proteção social do trabalhador e é fruto de lutas históricas por direitos trabalhistas e previdenciários. Santos (2007) aponta para a construção histórica da cidadania, de fato uma construção relacional que envolve a dimensão espacial de acesso aos direitos. Assim, quando falta saneamento básico, equipamentos de saúde ou a pessoa morre numa fila de espera por aposentadoria, demostra-se claramente os limites da cidadania. A Previdência Social no Brasil tem relação com as lutas sociais históricas da classe trabalhadora em diversos países. Este modelo de política se moderniza no Brasil nos anos de 1930, quando se reestrutura nos Institutos e Caixas de Pensões e Aposentadorias as categorias profissionais mais diversificadas, mas mantendo separação entre elas no formato de caixas de diferentes categorias profissionais. Em 1966, foram unificados e reunidos esses Institutos e Caixas, transformando-se no INPS (Instituto Nacional de Previdência Social), que era responsável pelos benefícios. Com a Lei ${ }^{\circ} 6.439 / 1977$, o INPS desdobra-se em duas novas instituições: o INAMPS (Instituto Nacional de Assistência Médica da Previdência Social), que passava a prestar conta das políticas de assistência médica; e o Instituto de Administração Financeira da Previdência e Assistência Social (IAPAS) ficando responsável pela arrecadação. É na década de 1990, no governo Collor de Mello, que o Congresso e o executivo vão discutir a modernização do sistema de saúde (Sistema único de Saúde - SUS, que havia sido criado com a Constituição de 1988) e do sistema previdenciário. Separa-se de vez a política de saúde da política de previdência e assistência social. Ocorre a junção entre o INPS e o Instituto de Administração Financeira da Previdência e Assistência Social (IAPAS) e é implementado Instituto Nacional de Seguridade Social (INSS), criado com base no Decreto $n^{\circ} 99.350$ de 27 de junho de 1990.

Atualmente, o Instituto Nacional do Seguro Social - INSS é uma entidade federal vinculada ao Ministério da Previdência Social - MPS, que tem por objetivo promover as políticas e ações de reconhecimento e conceder benefícios aos trabalhadores que contribuem de acordo com o Regime Geral de Previdência Social (RGPS), assim a Previdência se caracteriza como um seguro público contributivo. Portanto, é somente depois da promulgação da Constituição de 1988 que passa a ser obrigação e responsabilidade do Estado a Seguridade Social, garantindo ao segurado utilizar seus serviços em casos de aposentadorias por idade, por 
invalidez, por tempo de contribuição e em casos em que fique impossibilitado para o trabalho por motivos de doença, como o auxílio-doença; em casos de acidente como o auxílio-acidente; em caso de morte, deixando pensão para seus dependentes; em caso de prisão com o auxílioreclusão; em caso de gravidez com o salário maternidade. Os trabalhadores também podem contar com os serviços de reabilitação profissional, serviço social e perícia médica. É considerado contribuintes em Regime Geral da Previdência Social, de acordo com as seguintes categorias: Empresa, Trabalhador com contrato de trabalho (empregado assalariado, trabalhador avulso, prestador de serviço por tempo determinado e trabalhador doméstico), Contribuinte Individual (trabalhador autônomo ou equiparado e empresário, pequenas e médias empresas), Contribuinte Facultativo e Segurado Especial.

O segurado especial é uma das categorias de beneficiários da Previdência e é está respaldado pela Lei 11.718 de 20 de junho de 2009 que acrescenta artigo à Lei 5.889, de 8 de junho de 1973, e alteram a Leis 8.171, de 17 de janeiro de 1991, 7.102, de 20 de junho de 1993, 9.017, de 30 de março de 1995, e 8.212 e 8.213, ambas de 24 de julho de 1991. (Fonte: http://www.planalto.gov.br/ccivil_03/_Ato2007-2010/2008/Lei/L11718.htm).

É importante destacar que a primeira legislação de proteção ao trabalhador rural vai acontecer em 1963 (a Lei 4.214), o que veio afirmar direitos relacionados a categorias (como segurança, higiene do trabalho, regramento contratual e organização sindical), mas a aposentadoria, ou seja, o sistema de seguridade social, vai ser criada em 1967 junto ao FUNRURAL (Fundo de Assistência ao trabalhador rural), por meio do Decreto 276, voltado para a saúde e com colaboração ao sindicato dos trabalhadores rurais. É nesse contexto do FUNRURAL que os pescadores, assim como os agricultores, a partir de 1972 passam a ter a aposentadoria como direito, estando eles associados às colônias de pescadores que foram implementadas pelo Estado articulados ao Ministério da Agricultura (SILVA, 2015). O segurado especial refere-se, portanto, ao processo modernizador do sistema previdenciário no Brasil, em que integra diferentes grupos sociais.

O Segurado Especial é o produtor rural, o parceiro, o meeiro, e o arrendatário rural, incluindo o pescador artesanal, agricultor familiar, extrativista de vegetais e seus assemelhados, que exerçam suas atividades individualmente ou em regime de economia familiar, com ou sem auxílio eventual de terceiros, mutirão, a título de mútua colaboração. Todos os membros da família (cônjuges ou companheiros e filhos maiores de 16 anos de idade ou a eles equiparados) que trabalham na atividade rural, no próprio grupo familiar, são considerados segurados especiais também. Inclui-se ainda os povos indígenas, como beneficiários da Previdência Social, que assegura uma classificação especial aos indígenas como segurado especial. Segundo a Instrução Normativa $n^{\circ} 45$ do INSS, enquadra-se como Segurado Especial Indígena, a pessoa indígena reconhecida pela Fundação Nacional do Índio - FUNAI que trabalhe como artesão e utilize matéria-prima proveniente de extrativismo vegetal, ou o que exerça atividade rural individualmente ou em regime de economia familiar e faça dessas atividades o seu principal meio de vida e de sustento, independentemente do local onde resida ou exerça suas atividades. Vale ressaltar que é irrelevante a definição de indígena aldeado, indígena não-aldeado, índio em vias de integração, índio isolado ou índio integrado. Para todos esses trabalhadores, a inserção como segurado especial ocorre por meio da inscrição junto ao INSS, no sistema e necessitam declarar a sua produção e realizar contribuições mensais de no mínimo na alíquota de $20 \%$, sobre valores superiores ao salário mínimo, tendo como referência a produção mensal desse trabalhador rural. O trabalhador rural na categoria de segurado especial, pode requerer sua aposentadoria por idade, a contar com o mínimo 55 anos (mulher) e 60 anos (homem) e comprovar 15 anos de atividade, através dos documentos comprobatórios de sua profissão. A base de valor do benefício do Segurado Especial é de um Salário Mínimo.

O segurado especial que desejar receber valores superiores ao salário mínimo, de benefícios ou de aposentadoria, faz-se necessário filiar-se ao Regime Geral da Previdência 
Social como contribuinte individual, assim, terá direito tanto à aposentadoria sobre os salários de contribuição, quanto aos outros benefícios que asseguram os trabalhadores. Nesse processo de inscrição junto ao INSS, o cidadão obterá o Número de Inscrição do Trabalhador (NIT). Esse cadastro pode ser realizado em agência da Previdência Social ou pelo telefone 135, onde o trabalhador passará a contribuir na categoria de contribuinte individual na atividade de pescador artesanal, mas de forma a obedecer a calculabilidade do Estado. O valor do salário de contribuição será de $20 \%$ do salário mínimo (R\$ $1.045,00)$ até o teto do INSS, que é o limite máximo de contribuição do INSS (atualmente está no valor de R\$ 6.101,06). A contribuição deverá ser paga até o dia 15 do mês seguinte, a fim de garantir o cumprimento da carência, contando a partir do momento em que o cidadão faz o seu primeiro pagamento ao INSS, ou seja, a partir do primeiro pagamento realizado até a data de vencimento. Garantindo dessa forma que o contribuinte, ou em alguns casos o seu dependente, possa ter direito de receber um benefício.

No que se refere ao Regime Geral da Previdência Social, entre dados da população brasileira, em 2018, 207.853.293 habitantes, sendo que 178.373 .778 vivendo nas cidades e 29.479.512 habitando na área rural, quando comparado à população economicamente ativa (PEA - total de 103.877.923), sendo 90.922.864 população ocupada, 12.955 .059 desocupada e 65.654.097 população não economicamente ativa (65.654.097 pessoas) - Tabela 1. Da PEA, os trabalhadores classificados em atividades rurais (incluindo os pescadores artesanais) constam 209.390 habitantes, para uma realidade de 4.345.405 de pequenos e médios empregadores, 23.043.049 como com atividade por conta própria e 6.265.204 trabalhadores domésticos de acordo com a PNAD do IBGE (2018). Quando confrontado esses dados para o Regime Geral de Previdência privada (2018), 52.365.738 são contribuintes, sendo 39.344.909 empregados (trabalho assalariado), 9.920.445 contribuintes individuais (autônomos), 1.900.817 domésticos, 1.197.587 facultativos e somente 1.980 no bojo de segurados especiais (Tabela 2, Gráfico 1).

Tabela 1 - Dados Populacionais - 2018

\begin{tabular}{|lr|}
\hline \multicolumn{1}{|c|}{ Discriminação } & \multicolumn{1}{|c|}{ Total } \\
\hline População Residente & $\mathbf{2 0 7 . 8 5 3 . 2 9 3}$ \\
\hline Urbana & 178.373 .778 \\
\hline Rural & 29.479 .515 \\
\hline População Economicamente Ativa & $\mathbf{1 0 3 . 8 7 7 . 9 2 3}$ \\
\hline Ocupada & 90.922 .864 \\
\hline Desocupada & 12.955 .059 \\
\hline População Não Economicamente Ativa & $\mathbf{6 5 . 6 5 4 . 0 9 7}$ \\
\hline População Ocupada Segundo Posição no Trabalho Principal: & \\
\hline Total & $\mathbf{9 0 . 9 2 2 . 8 6 4}$ \\
\hline Empregados & $\mathbf{5 5 . 1 6 4 . 8 1 7}$ \\
\hline Com carteira de trabalho assinada & 33.002 .330 \\
\hline Funcionários públicos estatutários e militares & 7.671 .876 \\
\hline Outros e sem declaração & 10.913 .333 \\
\hline Trabalhador Doméstico & $\mathbf{6 . 2 6 5 . 2 0 4}$ \\
\hline Com carteira de trabalho assinada & 1.848 .189 \\
\hline Sem carteira de trabalho assinada e sem declaração & 4.417 .015 \\
\hline Conta Própria & $\mathbf{2 3 . 0 4 3 . 0 4 9}$ \\
\hline Empregador & $\mathbf{4 . 3 5 2 . 4 0 5}$ \\
\hline & \\
\hline Trabalhador familiar auxiliar & $\mathbf{2 . 0 9 7 . 3 9 0}$ \\
\hline & \\
\hline Contribuintes para instituto de previdência em qualquer trabalho & $\mathbf{5 7 . 9 4 9 . 2 8 6}$ \\
\hline
\end{tabular}


Tabela 2 - Quantidade de contribuintes/beneciários ${ }^{4}$ para o regime geral de previdência social - 2018

\begin{tabular}{llr}
\hline Total & $\mathbf{5 2 . 3 6 5 . 7 3 8}$ \\
\hline & Empregados & 39.344 .909 \\
\cline { 2 - 3 } Contribuinte Individual & 9.920 .445 \\
\cline { 2 - 3 } Trabalhador Doméstico & 1.900 .817 \\
\cline { 2 - 3 } & Facultativo & 1.197 .587 \\
\cline { 2 - 2 } & Segurado Especial & 684.959 \\
\hline
\end{tabular}

Fonte: MINISTÉRIO DA ECONOMIA/SPPS, 2020.

Gráfico 1. População economicamente ativa e População não economicamente ativa do Brasil - 2018

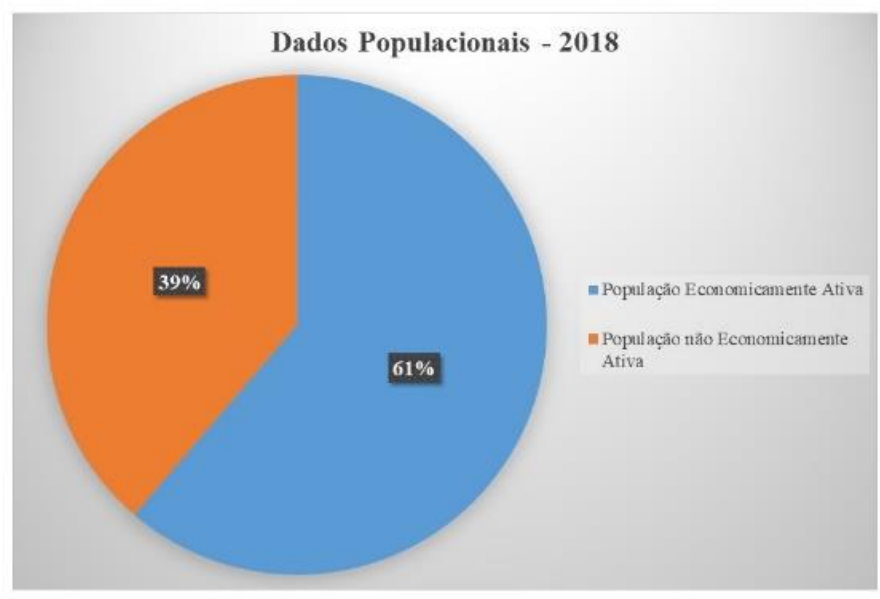

Fonte: MINISTÉRIO DA ECONOMIA/SPPS, 2020.

Tal análise referente às aposentadorias, contribui para compreender que boa parte dos trabalhadores rurais estão entre os facultativos (que pagam por 20 anos, na idade de 60 para homens e 55 para mulheres, podendo receber de 1 a 2 salários mínimos na aposentadoria), segurado especial (15 anos de comprovação de atividade, podendo se aposentar 60 anos para homens e 55 para mulheres, sem comprovação de pagamento ao INSS e recebendo um salário mínimo).

Desses valores quantitativos de contribuintes, 5.190.239 tiveram benefícios concedidos no acumulado em 2019, sendo 4.414 .384 pessoas beneficiadas nos trabalhos classificados urbanos, com um total de $\mathrm{R} \$ \mathbf{6 . 7 8 4 . 2 8 8 , 0 0}$ em contraste com 755.855 beneficiados no mesmo período para a categoria de atividades consideradas rurais, totalizando somente cerca de $\mathrm{R} \$$ 774.950. Os dados sobre o segurado especial ou mesmo o facultativo não foram disponibilizados no Boletim Estatístico da Previdência Social (2020).

Confrontando esses dados com as faixas de renda, observa-se que 99,26\% dos trabalhadores da categoria rural recebem como salário mínimo, enquanto as categorias urbanas são mais bem distribuídas, ficando $46,75 \%$ dos benefícios no valor de um salário mínimo e $37,37 \%$ entre 1 e 2 salários mínimos. Assim, dos valores correspondentes aos 755.855 beneficiados da categoria rural, 99,04\% tiveram valor de um salário mínimo nos benefícios concedidos (Gráficos 2 e 3). 


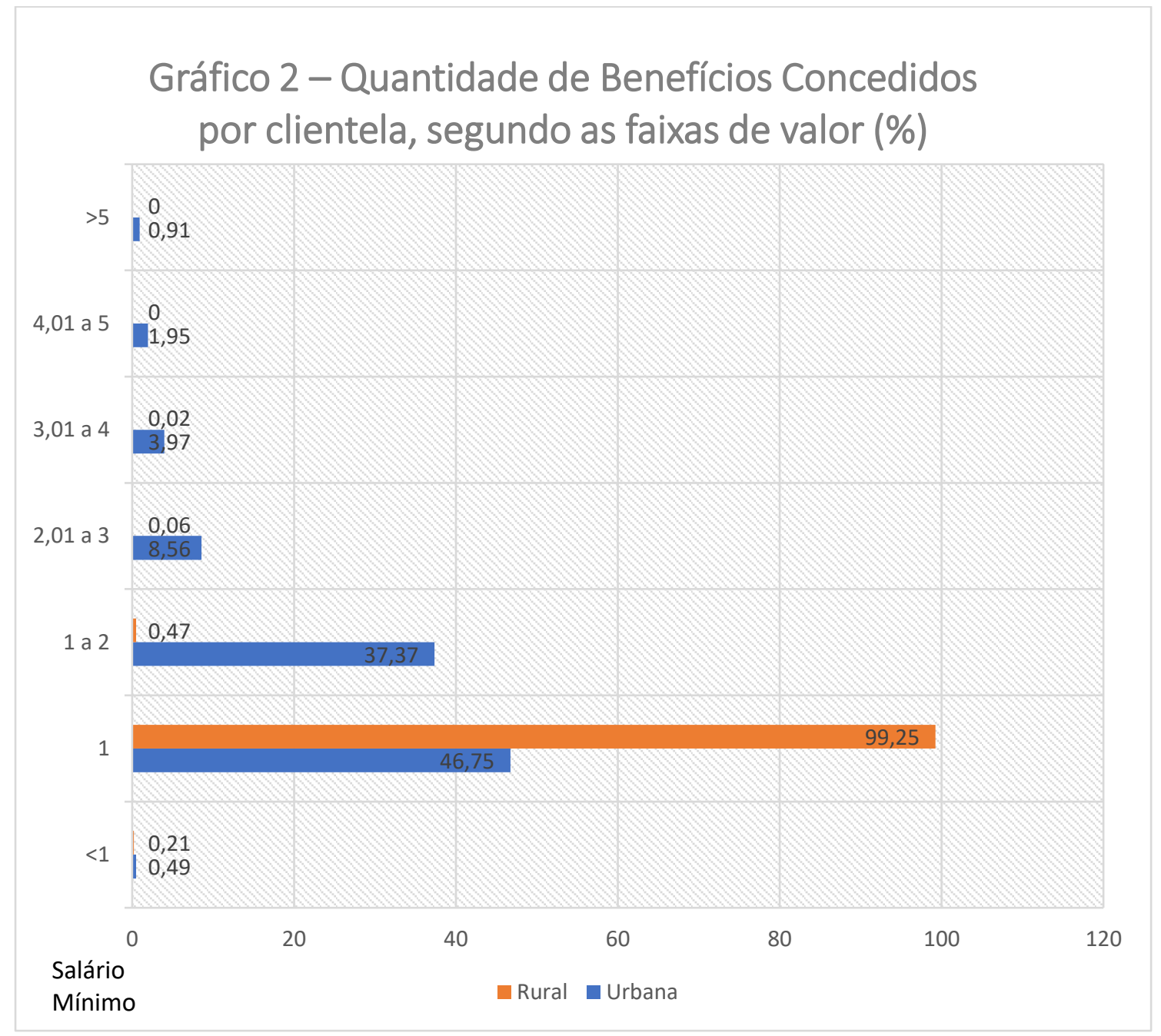

Fonte: MINISTÉRIO DA ECONOMIA/SPPS, 2020. 


\section{SM* Gráfico 3 - Valor de Benefícios Concedidos, segundo as faixas de valor (\%)}

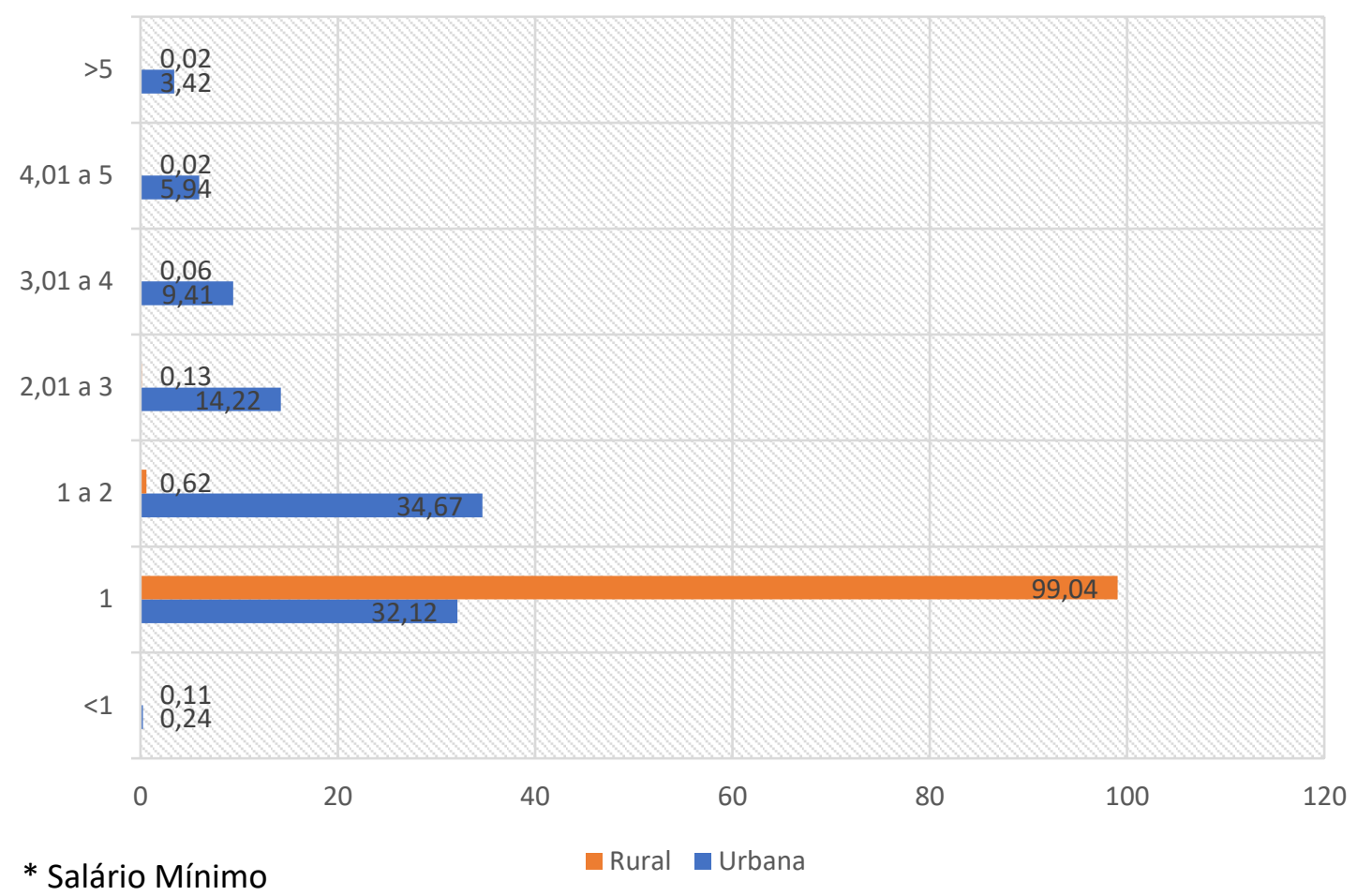

Fonte: MINISTÉRIO DA ECONOMIA/SPPS, 2020.

Esses dados nos levam à reflexão de que a categoria de segurado especial está muito inferior da realidade dos pescadores artesanais. Nos trabalhos de campo que efetuamos no Rio de Janeiro, entre 2008 e 2019, buscando compreender o perfil dos pescadores e pescadoras nas localidades das baías de Guanabara, Sepetiba e Ilha Grande, foi possível identificar que muitos pescadores não participavam como segurado especial. Alguns eram vinculados como contribuinte individual e como contribuinte facultativo e muitos, apesar da idade entre 50 a 60 anos, nunca pediram auxílio e alguns muito recentemente é que passaram a acessar o INSS. Os motivos são vários, entre eles a falta de documentação, a falta de estímulos em buscar os seus direitos, a dificuldade de compreensão de acesso aos sistemas de acesso aos benefícios (BUCH, 2016).

Para se ter acesso aos benefícios do INSS, e principalmente ao auxílio defeso, que se populariza entre os pescadores a partir de 2008, precisa estar cadastrado na Previdência como segurado especial, portanto como extrativista de pescados, marisqueiros, catadores. $\mathrm{O}$ auxílio defeso nasce a partir da Lei 20.779/2003 e de portarias entre o Ministério do Meio ambiente, o Ministério da Pesca, quando analisam o período de defeso das espécies marinhas (SILVA, 2015). A partir desse fato, os pescadores ficam proibidos de pescar a espécie e passam a ter direito ao auxílio defeso, que é comparado ao auxílio-desemprego, só que significa o valor de um salário mínimo durante o período de defeso da espécie declarada pelo trabalhador junto à inscrição no Registro Geral da Atividade Pesqueira (RGP do Ministério da Agricultura, Pecuária e Abastecimento - MAPA) e junto à Receita Federal (Cadastro Econômico de Pessoa Física CAEPF, que substitui, em 2018, a Matrícula CEI) (SAMPAIO, 2020).

Assim, a fim de garantir o acesso ao defeso e aos direitos previdenciários, o segurado especial deve realizar o Cadastro de Atividade Econômica da Pessoa Física (CAEPF) que está relacionado com a produção da atividade. O CAEPF é administrado pela Receita Federal que 
reúne informações das atividades econômicas exercidas pela pessoa física, substitui o Cadastro Específico do INSS (CEI) de pessoa física e torna-se importante para o cumprimento de obrigações tributárias. A norma que regulamenta o CAEPF é a Instrução Normativa RFB no 1.828 , de 2018. Entretanto, para se ter acesso ao seguro defeso, todos os membros da família precisam ter o RGP junto ao MAPA. Aqueles que não possuem, mesmo que exerçam atividades de apoio a pesca estão excluídos de receber o seguro defeso (SAMPAIO, 2020).

\section{Modernização do Sistema Previdenciário e estrutura informacional de acesso à política pública}

Nos contextos de fim do século XX com o advento da Terceira Revolução Industrial, marcado pela robótica, informática, pela globalização e novos arranjos espaciais da produção (SANTOS, 1996), a informatização entrou no sistema financeiro nos anos de 1980, com a finalidade não somente da agilidade que o sistema permite, mas da redução de custo com a mão de obra. Havia o projeto de redução de bancários e da ampliação dos "caixas eletrônicos" (SILVA, 2002; RIBEIRO \& SILVA, 2004). O processo de informatização do Estado não é nova, mas no Governo atual vem marcado pelo projeto de redução do número de funcionários públicos como solução do ajuste do Estado, somado à redução do gasto da Previdência Social.

Historicamente a Previdência Social é discutida pelas fragilidades do sistema, o que permite fraudes. A informatização de forma mais estruturada ocorre no final dos anos 1990, quando se estruturam os sistemas de identificação do trabalhador e amplia-se, em 2006, o uso da telefonia como mediadora informacional entre o beneficiário e o sistema previdenciário, mas sem substituir nesse momento a presença na agência da Previdência. A partir de 2019, passa a ser obrigatório o agendamento pelo telefone. Assim, as Centrais de Atendimento do INSS, que operam pelo telefone 135, ultrapassam os 55 milhões de ligações recebidas nos primeiros nove meses de 2018. As centrais do INSS estão localizadas em Caruaru (PE), Palmas (TO) e Salvador (BA), as três recebem juntas cerca de 230 mil ligações diariamente, o que está aquém do número de pessoas que procuram atendimento (Quadro 2).

Quadro 2- Histórico da criação da central de atendimento do INSS.

\begin{tabular}{|l|l|l|}
\hline Ano & Central & Observação \\
\hline 1994 & $\begin{array}{l}\text { criada a Central 191, conhecida com Cipis } \\
\text { - a Central de Informações } \\
\text { da Previdência Social }\end{array}$ & $\begin{array}{l}\text { servia para orientar e esclarecer a população sobre questões } \\
\text { previdenciárias. Os operadores do canal eram os próprios } \\
\text { servidores } \\
\text { do INSS. }\end{array}$ \\
\hline 1998 & criado o PrevFone no Distrito Federal & Com funcionários terceirizados \\
\hline 2005 & $\begin{array}{l}\text { criado o PrevFone na Bahia } \\
\text { funcionava em Salvador, mas depois de um tempo esse canal } \\
\text { foi encerrado. }\end{array}$ \\
\hline 2007 & $\begin{array}{l}\text { Começou a funcionar outra sede da } \\
\text { Central 135 }\end{array}$ & $\begin{array}{l}\text { Começou inicialmente em Recife } \\
\text { desta vez em Caruaru (PE). }\end{array}$ \\
\hline 2010 & $\begin{array}{l}\text { Central passou a ter mais } \\
\text { uma sede }\end{array}$ & $\begin{array}{l}\text { Instalada a Central 135 em Palmas (TO) } \\
\text { também em Belo Horizonte (MG) }\end{array}$ \\
\hline 2014 & mensais. \\
\hline
\end{tabular}

Fonte: Publicação do Ministério da Previdência Social, Ano III, $N^{\circ}$ 5, janeiro-abril de 2013. https://www.inss.gov.br/central-135-deatendimento-do-inss-supera-55-milhoes-de-ligacoes/

Em geral, o discurso da implementação da informatização vem junto com uma narrativa de melhoria de acesso do cidadão à política pública e às formas de desburocratização do sistema. Como passo à frente do processo de implementação da informatização do sistema, em 2018, é criado o MEU INSS, que se trata de uma plataforma digital em que o beneficiário mantém o 
contato com a Previdência e todo o histórico de ação, contribuição anual, solicitação de aposentadoria e solicitação de auxílios maternidade, saúde, dentre outros (Quadro 2). A partir de 2019 muitas agências foram fechadas através de uma política de diminuir os gastos e a ineficiência do atendimento. No entanto, para certificar a documentação anexada no sistema ainda é necessário ir à agência pessoalmente.

Além disso, a informatização do sistema de forma integrada (troca de dados entre os sistemas), que se inicia em 2015, entre Previdência Social, Receita Federal, Ministério do Trabalho e Ministério da Agricultura é um dos argumentos para a superação das fraudes.

No que se refere à compreensão de como a política pública estrutural se corporifica no território, a reflexão geográfica contribui para o entendimento do mundo existencial dos sujeitos. Observa-se, aquilo que o Manifesto do APPSULSE denuncia: a dificuldade de acesso ao sistema e de que, em pleno contexto de Coronavírus, muitos trabalhadores e trabalhadoras da pesca que tinham solicitado defeso, o sistema do INSS respondia como processo aguardando resposta. A esse problema, soma-se a questão dos beneficiários que solicitavam ainda aposentadoria ou qualquer outro auxílio no sistema e estavam impedidos de receber o auxílio emergencial, assim como aqueles pescadores que por falta de documentos (perdidos ou nunca solicitados), como o CPF (Cadastro de Pessoas Físicas da Receitas Federal), são negados o auxílio emergencial.

Já em 2018, apesar de difusão do Estado de que o acesso ao sistema informacional seria melhor para o cidadão, o Sindicato dos Empregados no Comércio do Distrito Federal (SINDICOM) avisavam que se o INSS não oferecer o suporte necessário, propagando e ensinando os trabalhadores a usarem o aplicativo, essa medida só vai prejudicar o cidadão. (CORREIO BRASILIENSE, 16/07/2018).

Fundamental explicar que a modernização do sistema previdenciário com os usos das tecnologias de comunicação e informação têm, além de "agilizar a inserção da política pública para o cidadão", como afirmam, se inscrever no modelo de redução do número de trabalhadores. Em 2019, dos 35 mil funcionários na ativa, cerca de 12 mil tinham o direito de se aposentar. Nos últimos 10 anos tem sido reduzido o número de funcionários e o Ministério Público Federal já havia ajuizado a necessidade de novo concurso público. A modernização se aproxima cada vez mais do sistema financeiro no país. O recadastramento anual do aposentado é feito pelos bancos e em 2019 o aplicativo MEU INSS se torna obrigatório a qualquer pessoa para se ter acesso à Previdência Social. O discurso da desburocratização no território torna-se frágil, pois a inscrição na plataforma não é fácil, em vez de acessar o corpo do funcionário público federal, os bancos mais uma vez são chamados a fazer a mediação tecnológica, ou seja, fortalece-se a articulação com o sistema financeiro, pois o "cadastro no Meu INSS pode ser feito pelo próprio aplicativo ou pelo site das seguintes instituições financeiras: Banco do Brasil, Banese, Banrisul, Bradesco, Itaú, Caixa Econômica Federal, Santander e Sicoob” (INSS, s/d2).

Milton Santos (1996) chamou atenção para a natureza do espaço no que se refere à contemporaneidade. Reconhece que o espaço geográfico tem se revelado como meio técnicocientífico-informacional e com o advento da aceleração das mediações tecnológicas no Estado, observamos que esse meio é geograficamente e socialmente diferenciado. Muitas localidades de pescadores e de agricultores não têm acesso à internet e quando têm apresentam fragilidades. Muitos não têm recurso para a compra de equipamentos ou ficam na dependência de outras pessoas ou lojas de prestação de serviços. Além disso, há uma nova linguagem instituída, seja na manipulação da plataforma, seja na manipulação do computador e dos smartphones. Sem dúvida, os mais velhos e mais pobres, que já vivem em condições de vulnerabilidades, também se tornam os mais frágeis com esse processo de modernização que se diz para melhorar o acesso do cidadão. É essa estrutura perversa que muitas vezes se constata quando olhamos para o território nacional e observamos as fortes desigualdades socioespaciais e a coerção em impor à sociedade as novas formas de consumo. 


\section{Contradições estruturais e conjunturais em tempos de coronavírus}

A mídia apresenta todos os dias uma enxurrada de notícias sobre o acesso às políticas públicas estruturais e emergências. Como já foi apontado nesse artigo, os pescadores artesanais e demais trabalhadores têm esperado há mais de 45 dias respostas do INSS. Conforme podemos observar também no Gráfico 3, Figuras 1 e 2, a seguir:

Gráfico 3 - Percentuais de Requerimento de Benefícios por região do Brasil em 2020

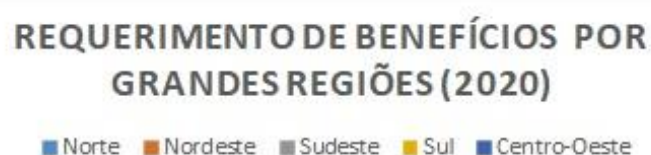

worte $\mathbf{m}$ Nordeste $\mathbf{m}$ Sudeste $\mathbf{m}$ Sul $\mathbf{m}$ Centro-Oeste

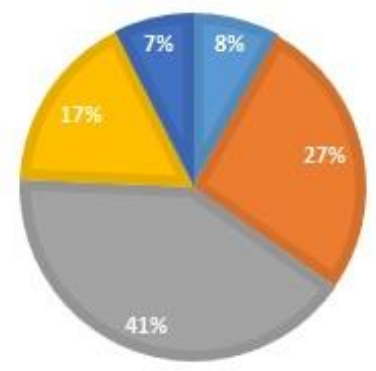

Fonte: MINISTÉRIO DA ECONOMIA/SPPS, 2020.

Figura 1. Requerimentos em análise por Unidade da Federação até 45 dias de espera de resposta do INSS - 2019

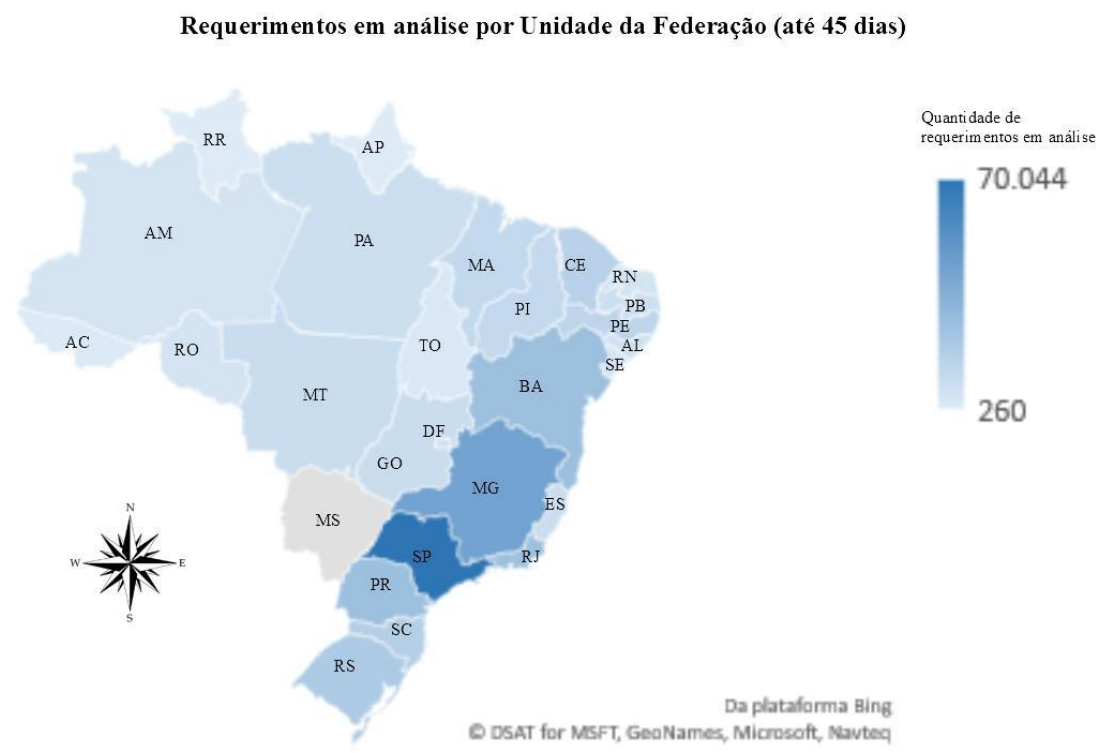

Fonte: MINISTÉRIO DA ECONOMIA/SPPS, 2020. 
Figura 2. Requerimentos em análise por Unidade da Federação mais de 45 dias de espera de resposta do INSS - 2019

Requerimentos em análise por Unidade da Federação (acima de 45 dias)

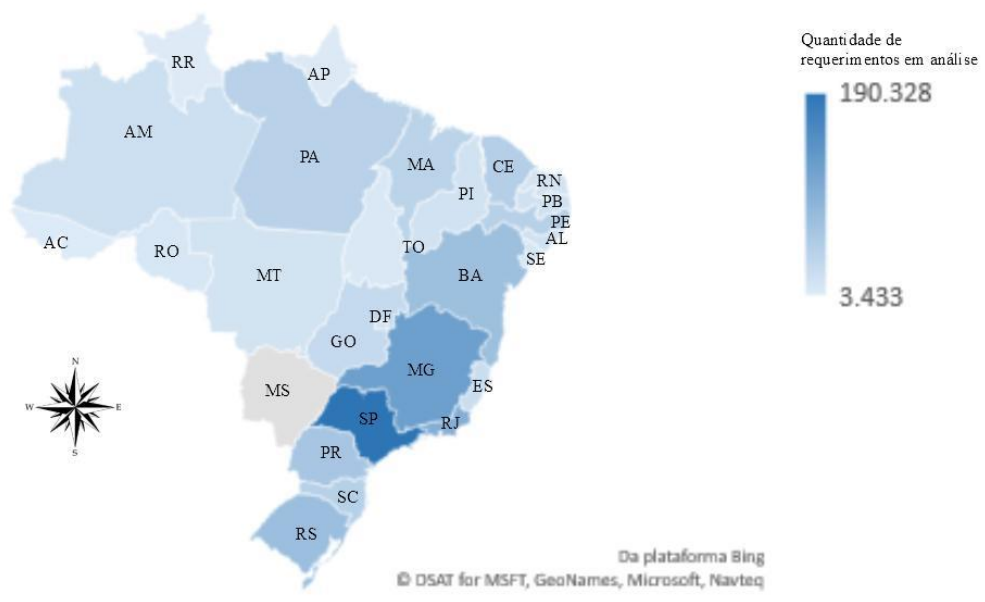

Fonte: MINISTÉRIO DA ECONOMIA/SPPS, 2020.

Dos 1.416.736 dos requerimentos de benefícios em análise, 1.065 .736 ficaram aguardando resposta do INSS mais de 45 dias. O que demostra a crise no sistema, sendo que boa parte dessa crise se refere à falta de um número adequado de funcionários para atendimentos (Figura 2). Com a crise do coronavírus, a partir de 16 de março, a situação fícou mais difícil. Por exemplo, quem solicitou auxílio-doença, por motivo de impedimento do trabalho e que não teve tempo de fazer a perícia e se tiver com sintomas da COVID-19 somente serão atendidos depois da quarentena (A GAZETA, 2020).

Diante dos conflitos existentes e muitos coletivos e movimentos reivindicando, em 16 de abril o INSS divulga que suspende exigências para o segurado especial rural pelo prazo de 120 dias. O objetivo é "agilizar o atendimento e resguardar os direitos dos beneficiários em razão da pandemia do coronavírus". O que foi suspenso no prazo de 120 dias foi a autenticação de documentos na agência da Previdência e os prazos para cumprimento de exigências dos segurados especiais rurais que não puderem ser cumpridas pelos canais remotos - ou seja - os limites legais de 45 dias, que já não vinha sendo cumprido pelo Estado. A medida, normatizada na Portaria 295 e publicada no Diário oficial da União, visa resguardar os direitos desses segurados enquanto durar o estado de emergência de saúde no país, devido à pandemia do coronavírus. Além disso, vale ressaltar que nas situações em que houver dúvida fundada quanto à documentação apresentada, "o INSS fará as exigências que forem necessárias. No entanto, o prazo para o cumprimento das mesmas também ficará suspenso até o retorno do atendimento presencial" (INSS, s/d1). 
PORTARIA No 295/DIRBEN/INSS, DE 15 DE ABRIL DE 2020

Dispõe sobre o atendimento de beneficiários segurados especiais em razão da pandemia do coronavírus (COVID-19)

O DIRETOR DE BENEFÍCIOS DO INSTITUTO NACIONAL DO SEGURO SOCIAL - INSS, no uso das atribuições que lhe confere o Decreto $\mathrm{n}^{\circ}$ 9.746, de 8 de abril de 2019, e considerando a necessidade de estabelecer orientações e diretrizes preventivas para evitar o deslocamento de usuários às Agências da Previdência Social durante o estado de emergência de saúde pública de importância internacional decorrente da pandemia do Coronavírus (COVID-19) e CONSIDERANDO a Portaria ${ }^{\circ} 412 /$ PRES/INSS, de 20 de março de 2020,

RESOLVE:

Art. $1^{\circ}$ Adotar as seguintes medidas, para resguardar os direitos dos segurados especiais rurais

enquanto perdurar a situação e emergência de saúde pública de importância internacional decorrente

do coronavírus:

I - dispensa de autenticação de cópias de documentos específicos nas unidades de atendimento, por prazo determinado, nos termos dos Arts. $8^{\circ}$ e $9^{\circ}$ do Decreto $n^{\circ} 9.094$, de 17 de julho de 2017; e

II - suspensão dos prazos para cumprimento de exigências que não puderem ser cumpridas pelos

canais remotos.

Fonte: (INSS, s/d1).

Em função das questões conjunturais e por motivo de temor a judicialização, o INSS, em 19 de abril de 2020, lança novas notícias. Sobre novas medidas (Portaria 295/2020 do DIRBEN/INSS) em função da pandemia do coronavírus no Brasil, vem esclarecer que a partir dessa data o INSS, em conjunto com a Perícia Médica Federal, dispensará o segurado da necessidade de comparecer em uma agência para a perícia médica presencial e agora passa a incluir o cidadão com COVID-19. Dessa forma, os segurados que fizerem requerimentos de auxílio-doença e Benefício de Prestação Continuada (BPC) para pessoa com defíciência devem enviar o atestado médico pelo Meu INSS, aplicativo ou internet. A medida tem por objetivo assegurar a saúde dos cidadãos, em especial a dos idosos (INSS, s/d2). E afirma que o ato oficial seria publicado no dia 20 de abril. Refere-se ainda ao fato de que o atestado poderá ser enviado on line ao sistema do MEU INSS e que essa medida evitará a ida das "milhares de pessoas à agência". Com o fechamento das agências da Previdência Social, o modelo que reforça a informatização se torna mais acentuado e demonstra as fragilidades dos sistemas.

\section{Retomando a questão do Pescador ao auxílio emergencial}

Conforme apontaram os pescadores artesanais, pequenos agricultores, extrativistas e indígenas no contexto de segurado especial estariam fora do direito de auxílio emergencial, conforme relataram os pescadores nas entrevistas, uma vez que a lei estava voltada sobretudo ao trabalhador urbano - desempregado, autônomo e microempresário, somando-se os trabalhadores do setor informal quase que invisíveis ao Estado. $O$ resultado tem sido interessante: o número de pessoas reivindicando o auxílio foi maior do que o previsto, o que demostra as fragilidades dos estudos sobre pobreza a informalidade por parte do Estado do Brasil. O segundo elemento interessante é a dinâmica da conjuntura com mudanças permanentes e os conflitos entre as ideologias neoliberais que apontam o limite orçamentário do Estado e as ideologias desenvolvimentistas e "keynesianas", o que nos levaria à produção de outro artigo. Como nosso objetivo é compreender como a política pública se realiza no território e quais os impactos na vida do pescador, o que podemos dizer é que as famílias de pescadores que recebem bolsa família tiveram acesso ao auxílio emergencial. Daqueles que não tinham nenhum acesso às políticas públicas, alguns fizeram a inscrição no aplicativo elaborado para esse fim e estão aguardando, enquanto aqueles sem CPF estão nas filas da Receita Federal buscando agilizar e se sentindo até "humilhados", como relatam. Outros como segurado especial, fizeram o cadastro do auxílio, alguns receberam e outros não. Desde o mês de março, antes de ser assinado pelo Presidente da República, o Congresso Nacional recebeu vários 
manifestos dos grupos de trabalhadores que se sentiam excluídos e de fora dos critérios. $\mathrm{O}$ Manifesto do APPSULSE, por exemplo, citava a especificidade do segurado especial, com ênfase aos pescadores e agricultores e demais comunidades tradicionais. Assim, no dia 22 de abril essas reivindicações foram ouvidas, entretanto, em parte, porque embora contempladas na letra da lei, ainda enfrentam as dificuldades e barreiras estruturais de acesso e efetivação dos direitos, como discutidos nesse artigo. O plenário aprovou o substitutivo da Câmara dos Deputados ao projeto do Senado (PL 873/2020) que amplia o alcance do auxílio emergencial a ser concedido a trabalhadores urbanos e rurais em condição de vulnerabilidade, entre eles: pescadores profissionais e artesanais, aquicultores, marisqueiros e os catadores de caranguejos e agricultores familiares, arrendatários, extrativistas, silvicultores, beneficiários de programas de crédito fundiário, técnicos agrícolas, assentados da reforma agrária, quilombolas e demais povos e comunidades tradicionais prejudicados pela pandemia de coronavírus (SENADO FEDERAL, 22/04/2020). O texto recebeu voto favorável de 80 senadores (o que representa unanimidade, porque o presidente da sessão não vota) e segue agora para a sanção presidencial.

\section{Considerações finais}

O presente artigo buscou analisar a conjuntura de crise societária coronavírus no contexto da análise da estrutura da Previdência Social e de como os pescadores artesanais, que fazem parte da população mais pobre do país, se inserem na política pública previdenciária. Ao finalizar esse artigo, em 30 de abril de 2020, quando o Brasil faz parte dos 10 países mais atingidos pela pandemia, quer seja nos dados estatísticos oficiais de infectados, quer seja nos dados oficiais de morte por COVID-19, muitos desses trabalhadores ainda não conseguiram o auxílio emergencial e nem conseguiram o auxílio defeso. Muitos têm dificuldade de vender o produto e por isso diminuíram a sua renda e outros doentes, por diversos problemas, quer seja ocupacionais, quer seja outras enfermidades, incluindo o COVID-19, mas com muita dificuldade de acessar o sistema público em que quase $100 \%$ dos leitos de UTI já estão ocupados, com aumento diário de pessoas na fila aguardando vagar leitos, vivendo um verdadeiro pandemônio no sentido de dificuldades de acesso à saúde a ao direito trabalhista e/ou assistencial. As agências do Banco da Caixa Econômica (onde também recebem o auxílio defeso) estão lotadas porque os aplicativos da política emergencial estão permanentemente com problemas, apesar da atenção dos epidemiologistas alertarem para o risco da proliferação do vírus. Enfim, a crise do coronavírus é uma crise societária e põe em dúvida o modelo de Estado, de Política Pública e de acesso aos direitos básicos da vida coletiva.

O presente artigo contou com a participação coletiva do NUTEMC - Núcleo de Pesquisa e Extensão Urbano, Território e Mudanças Contemporâneas da Faculdade de Professores da Universidade do Estado do Rio de Janeiro. E as análises da política pública da previdência social na vida dos pescadores é um exercício que vimos fazendo, desde 2011, junto aos projetos de extensão "Pescando por meio de redes sociais" e de pesquisa "Modernização, território e cartografia da ação social: Análise da Cadeia produtiva, das condições de trabalho e das formas de luta dos trabalhadores da Pesca Artesanal no Rio de Janeiro". Gostaríamos de agradecer aos pescadores artesanais da Pedra de Guaratiba - cidade do Rio de Janeiro, ao Fórum de Pescadores da Baía de Sepetiba e aos pescadores e pescadoras da Articulação de Pescadores e Pescadoras do Sul e Sudeste (APPSULSE), que dialogaram conosco e, assim, contribuíram com informações e relatos nesse contexto conjuntural, que só acirra as desigualdades reais de acesso às políticas de Estado no Brasil. 


\begin{abstract}
Notas
1 - Coordenadora do NUTEMC/FFP/UERJ, Pesquisadora do CNPq.

2 - Portaria Conjunta INSS/MDSA No 1 DE 03/01/2017 - Publicado no DOU em 4 jan 2017. Portaria Conjunta INSS/MDSA No 1 DE 03/01/2017. Regulamenta regras e procedimentos de requerimento, concessão, manutenção e revisão do Beneficio de Prestação Continuada da Assistência Social - BPC. Publicado no DOU em 4 jan 2017. 3 - O recurso envolvido na operação veio da medida provisória editada pelo governo no início de abril para financiar o programa (MP 937/2020). Foram liberados R $\$ 98,2$ bilhões em créditos extraordinários para o Ministério da Cidadania dar auxílio emergencial "de proteção social a pessoas em situação de vulnerabilidade devido à pandemia da covid-19”. A MP ainda não foi votada pela Câmara.

4 - Inclui-se aposentadoria por contribuição, aposentadoria por idade, aposentadoria por invalidez, auxílio maternidade, auxílio-doença, pensão por morte, acidente de trabalho, auxílio pessoa com deficiência
\end{abstract}

\title{
Referências Bibliográficas
}

A GAZETA. Auxílio-doença será pago pelo INSS só após quarentena do Coronavírus, 2020. Disponível em www.agazeta.com.br/es/economia/auxílio-doença-sera-pago-pelo-inss-so-aposauarentena-por -coronavirus-0320. Consulta 20/04/2020.

APPSULSE. Manifesto contra as formas de exclusão aos direitos dos pescadores artesanais e agricultores familiares da política emergencial \#coronavirusBrasil\# , 2020. Disponível: https://articulacao-dos-pescadores-e-pescadoras-do-sul-sudeste8.webnode.com/. Consulta: 15/04/2020.

Bobbio, Norberto. O futuro da democracia: uma defesa das regras do jogo. Trad. Marco Aurélio Nogueira. Rio de Janeiro, Paz e Terra, 1986. 171 p.

BUCH, Carolina, L. As Lutas dos Pescadores Artesanais pelo Acesso aos Direitos Sociais: Estudo sobre as Políticas Previdenciárias e Trabalhistas. Monografia de Graduação em Licenciatura em Geografia. Departamento de Geografia da Faculdade de Formação de Professores - UERJ, 2016.

COAD - NOTÍCIAS. Trabalhador Rural. Segurado especial terá novas regras para comprovar atividade rural. 18 de Março de 2019. Disponível em: http://www.coad.com.br/home/noticiasdetalhe/92430/segurado-especial-tera-novas-regras-para-comprovar-atividade-rural.

Consulta 20/04/2020.

CORREIO BRASILIENSE. INSS lança aplicativo para agilizar atendimento a usuários da Previdência. 16/07/2018. Disponível em: https://www.correiobraziliense.com.br/app/noticia/economia/2018/07/16/internas_economia,695324/in ss-lanca-novo-atendimento-para-usuarios-atraves-de-aplicativo.shtml. Consulta em 25/04/2020. Consulta 20/04/2020.

FREITAS, Andre V. Estado, território, ambiente e políticas públicas: o ordenamento territorial e sua interface ambiental. In: RAMOS FILHO, Eraldo da S. et. al. Estado, políticas públicas e território: São Paulo: Outras Expressões, 2015, 199-220

INSS. Suspensão das existências do segurado especial - COVID-19. s/d1.. Disponível em: https://www.inss.gov.br/inss-suspende-exigencias-para-o-segurado-especial-rural-pelo-prazo-de-120dias/ Consulta 20/04/2020.

INSS. Telefone 135 INSS - Atendimento. s/d2. Disponível em: https://previdenciasocial.net.br/inss/telefone-135-inss-atendimento. Consulta: 30/04/2020.

MARX, KARL. O 18 Brumário de Luis Bonaparte, São Paulo, Ed. Escriba Ltda, 1968 [1852].

MINISTÉRIO DA ECONOMIA/SPPS. Boletim Estatístico da Previdência Social. V. 25, N.2, Fevereiro de 2020.

Ministério da Previdência Social, Ano III, $\mathrm{N}^{\circ}$ 5, janeiro-abril de 2013. Disponível em: https://www.inss.gov.br/central-135-de-atendimento-do-inss-supera-55-milhoes-de-ligacoes/. Consulta: 20/04/2020.

OMS. Coronavirus (COVID-19). 30/04/2020, disponível: https://covid19.who.int/. Consulta: 
$30 / 04 / 2020$.

POULANTZAS, Nicos. O Estado o poder, o socialismo. Rio de Janeiro: Graal, 2000.

RAFFESTIN, Claude. Por uma Geografia do poder. Tradução: Maria Cecília França. São Paulo: Ática, 1993.

RESENDE, Alberto Toledo. O papel do Estado no controle territorial e sua relação com a estruturação da atividade pesqueira brasileira na Primeira República. 2010. 153 p. Dissertação (Mestrado em História Social do Território) - Universidade do Estado do Rio de Janeiro / Faculdade de Formação de Professores, São Gonçalo, 2010.

RIBEIRO, Ana Clara T. Relações Sociedade-Estado: elementos do paradigma administrativo. In: RIBEIRO, Ana Clara T. Por uma sociologia do presente: ação, técnica e espaço- Volume 5. Rio de Janeiro: Letra Capital, 2013, v.3. p.95-116.

IBEIRO, Ana Clara T. Teorias da ação e análise de conjuntura. Rio de Janeiro: Letra Capital, organizadores: Fabio Tozi e Naila Takahashi, 2014.

RIBEIRO, Ana Clara Torres \& SILVA, Catia Antonia. Impulsos Globais e espaço urbano: sobre o novo economicismo. In RIBEIRO, Ana C. T. (orgs.) O rostro urbano de América Latina. Buenos Aires: CLACSO, 2004. p. 56-68.

SAMPAIO, Karla da $\mathrm{S}$. Os pescadores artesanais e o meio-técnico-científico informacional: modernização do sistema público e impactos nos direitos trabalhistas dos pescadores. Monografia de Graduação em Licenciatura em Geografia. Departamento de Geografia da Faculdade de Formação de Professores - UERJ, 2020 (prelo).

SANTOS, Milton. A natureza do Espaço: técnica e tempo, razão e emoção. São Paulo: HUCITEC, 1996, 308p.

SANTOS, Milton Por uma outra Globalização: do pensamento único à consciência universal. Rio de Janeiro: Record, 2000.

SANTOS, Milton. O espaço do cidadão. São Paulo: EDUSP. 2007.

SENADO FEDERAL, Agência Senado. Notícias 22/04/2020. disponível em https://www12.senado.leg.br/noticias/materias/2020/04/22/expansao-do-auxilio-emergencial-seguepara-sancaopresidencial?fbclid=IwAR0eG4FkVcmeGG_47FqRQxCpC_FLd22BR4Zks71wU9Xd37oA1hMn5EF hyxE. Consulta 20/04/2020.

SILVA, Catia A. Política pública e território: passados e presente da efetivação de direitos dos pescadores artesanais no Brasil. Rio de Janeiro: Consequencia, 2015.

SILVA, Catia A. Qualificação profissional na construção do Brasil urbano moderno: secularização e sociedade, modernização e espaço. Orientadora: Júlia Adão Bernardes, Coorientadora: Ana Clara Torres Ribeiro. Rio de Janeiro: PPGG/UFRJ, 2002. Tese (Doutorado).. Rio de Janeiro: Universidade Federal do Rio de Janeiro, 2002

SOUZA SANTOS, Boaventura de. Pensar el Estado Y la sociedad: desafios actuales. LA PAZ: CLACSO, 2008.

UOL. Economia. Reportagens especiais: Filas e atrasos por falta de funcionários. 2018. Disponível em: https://economia.uol.com.br/reportagens-especiais/inss-filas-atrasos-falta-funcionarios/\#tematico-8. Consulta 20/04/2020.

WEBER, Max. Economia e sociedade. Volume 1. Brasília: Editora UNB, 2000. 